\title{
The ground stone components of drills in the ancient Near East: Sockets, flywheels, cobble weights, and drill bits
}

\author{
David Ilan
}

Hebrew Union College, Jerusalem, Israel. Email: dilan@huc.edu

\begin{abstract}
:
Three types of drills are known from antiquity: the bow drill, the pump drill and the crank drill. Each type often included ground stone components - sockets, weights and flywheels. However, these components are inconspicuous; on their own they are almost never associated with drills. The result is that the drill is nearly invisible in many assemblages, particularly those of the proto-historic and historic periods, from the Chalcolithic through to late antiquity. In this article I focus on the identification of the possible ground stone components of each of these drill types. The means by which these components were attached or applied to the drill shaft is examined and the way that they related to the rotary motion of drills is laid out. I briefly discuss the historical development of each type, referencing more detailed studies, where available. This study should be seen as a prelude to a more comprehensive study that will test hypotheses by means of experiment and catalogue more completely and precisely the ground stone components of drills that have been unidentified or misidentified in archaeological contexts.
\end{abstract}

Keywords: bow drill; pump drill; crank drill; flywheel; Near East; ground stone tools

\section{Introduction}

Drilling is, and always has been, an essential manufacturing activity. In modern-day industrial societies drilling is practiced infrequently in the daily lives of most people, but in antiquity drilling was a routine action both for the making of fire and in artefact fabrication and decoration. Several studies have investigated drilling apparatus in the ancient Near East, particularly in the Egyptian context (e.g., Petrie 1884; 1917; Lucas \& Harris 2012: 42-44, 6671, 104-105, 423-426, 499; Hartenberg \& Schmidt 1969; Gorelick \& Gwinnett 1987; Moorey 1994: 103-110; Stocks 2003; Saraydar 2012). Stocks (2003) is widely considered the most comprehensive.

If we narrow our geographical purview to the Levant, recent work has focused on the use of the drill in Natufian and Neolithic contexts: Goren-Inbar et al. (2012) investigated clay cylinders that may have functioned as spindles for fire making; Grossman \& Goren-Inbar (2007) discussed the use of drills in the quarrying of flint nodules; and Wright et al. (2008) analysed the remains of a bead manufacturing workshop.

Published by the School of History, Classics and Archaeology, University of Edinburgh ISSN: 2055-0472. URL: http://journals.ed.ac.uk/lithicstudies/

This work is licensed under a Creative Commons Attribution 2.5 UK: Scotland License. 
Notwithstanding the above researches, the 'ground stone components' of drilling are striking in their absence from excavation reports of Levantine sites from virtually all archaeological periods. One of the few exceptions are the small-find catalogues published by Sass \& Cinamon (2006) and Sass (2004a) where ground stone artefacts associated with drilling are at least identified in the excavation reports of work at Tel Megiddo and Tel Lachish, respectively. But even here there is no discussion of the manufacture, use, and context of these stone artefacts.

This paper presents a roster and the criteria for identification of the various ground stone artefacts, which can, and often should, be associated with drilling. Since this volume deals with ground stone, I do not address chipped stone or metal drill bits, an artefact type which has been the subject of other studies (e.g., Gwinnett \& Gorelick 1987; 1993; Moorey 1994: 103-110; Rosen 1997: 68-71; Endo et al. 2009; Morero 2011). I start with the bow drill, which, in heavy-duty work, entails the use of a cap-stone, or drill socket. We then proceed to the pump drill, which involves a flywheel that is often made of stone. Finally, we look at the twist-reverse-twist, or crank drill, whose weights would have usually taken the form of stone cobbles (in $3^{\text {rd }}-2^{\text {nd }}$ millennium BCE contexts) or wheels (in $2^{\text {nd }}$ and $1^{\text {st }}$ millennium BCE contexts), and whose drill bits would have been of ground stone.

\section{The Bow Drill}

The bow-drill is well-known from ethnographic observation and from ancient Egyptian depictions (e.g., Petrie 1917: 39: Gorelick \& Gwinnett 1987; Stocks 2003: 23-24, 42-46; Saraydar 2012). The bow drill was probably used for fire-making more than anything else, but it was also an essential tool in craftwork, especially for carpentry, lapidary work, and beadmaking.

\subsection{Bow drill components}

The bow drill is comprised of a spindle, stock or shaft (generally of wood), a bow (which induces the rotary motion of the spindle), and a drill-socket, which allows a broad grip so as to apply downward pressure, creating friction and abrasion at the lower working end (Figure 1). When a fire ember is the goal there will be a notched wooden fireboard at bottom, upon which the tapered end of the wooden spindle is rotated to create an ember. In this case there will be no drill bit. A piece of skin or bark will underlie the fireboard to catch the ember and transport it to the kindling material (demonstrations of the fire-making process can be readily accessed on YouTube by searching "bow drill”, see for example, National Geographic Channel 2014). For a demonstration by Denys Stocks of the ancient Egyptian stone coring technique using a bow drill, large stone drill socket and a tubular bit of copper, see: Science Channel 2009.

The heavy-duty drilling required for carpentry, bead-making and bone and ivory work demanded a bit, inserted in the working end of the spindle. In prehistoric periods this would have been of chipped stone (flint or chert), and in the Bronze Age, of copper or bronze (Gwinnet \& Gorelick 1987: 15-16; Stocks 2003: 142). It has been pointed out that copper drill bits are probably underreported in excavation reports dealing with sites in the Levant, due to their small size and lack of distinguishing characteristics (Yahalom-Mack 2009: 123, table III:6). In the Iron Age, iron might be used, though this may have been an even later development. Here we are concerned only with the drill socket made of ground stone. Egyptian wall reliefs depicting carpentry show drill sockets clearly (Figure 2). Therefore, we should expect to find them in the archaeological record as well. 


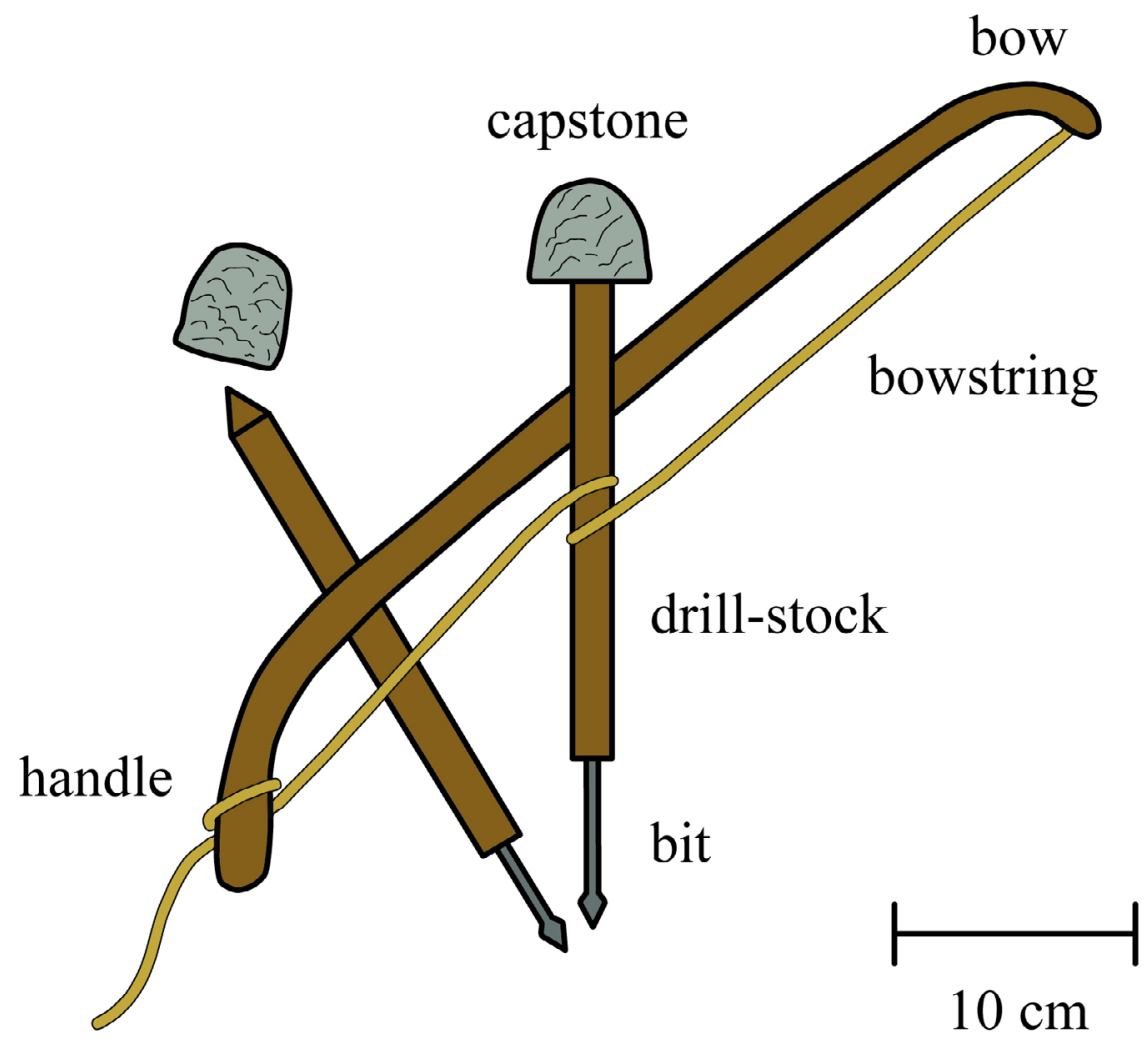

Figure 1. The components of a bow drill (after Wilkinson 1878: fig. 171).

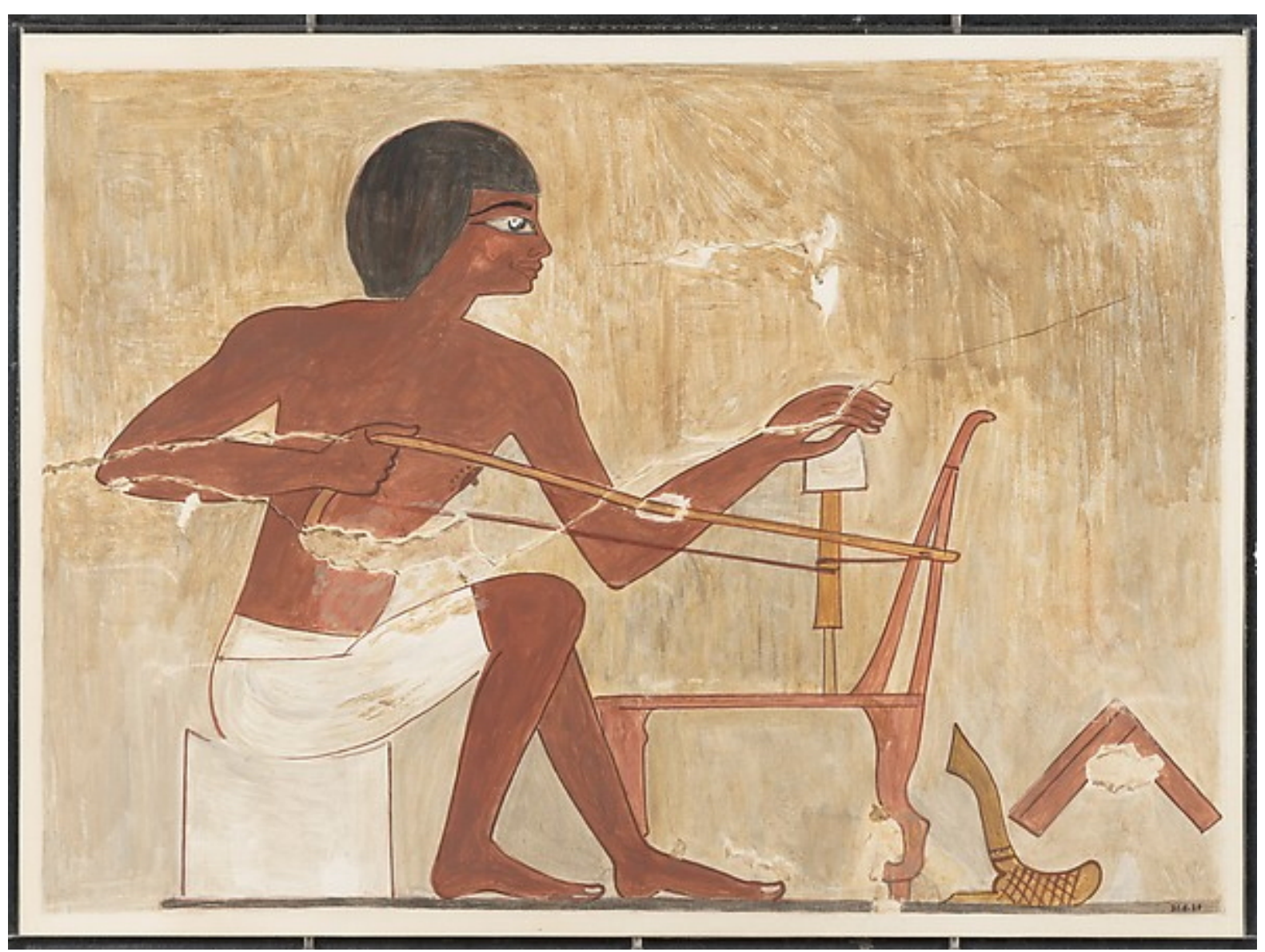

Figure 2. A wall relief from the Tomb of Rekhmire (Theban Tomb 100) showing the drilling operation (Davies 1935: pl. 52). Note the drill socket grasped by the workman at the top of the spindle. 


\subsection{Nomenclature}

The stone artefact used to exert downward pressure on the spindle is given different names in the literature: drill cap, capstone, handhold, hand piece, bearing block, or drill socket. Here, I adopt the last term: 'drill socket'. The drill socket can be fashioned of various hard materials: wood, bone, or stone. A wood or bone handhold is perfectly acceptable for producing a fire-starting ember. Unfortunately, wooden examples are bound to be virtually absent from the archaeological record. Bone drill-sockets will show up from time to time (e.g., Sass \& Cinamon 2006: fig. 18.30:653). Stone sockets are the most likely to survive and it is these with which we are concerned.

\subsection{Ground stone tools features and typological identification}

Wright's (1992) widely used Classification System for ground stone tools from the Prehistoric Levant lacks a type with the designation of a capstone, drill socket or hand-hold. But her "pebble mortar" (Type 15) and her "potlid" platter (Type 115) are likely to be drill sockets. Shallow sockets would suit fire drills, while deep, robust sockets would be more suitable for carpentry and masonry drilling (Figures 2 and 3).

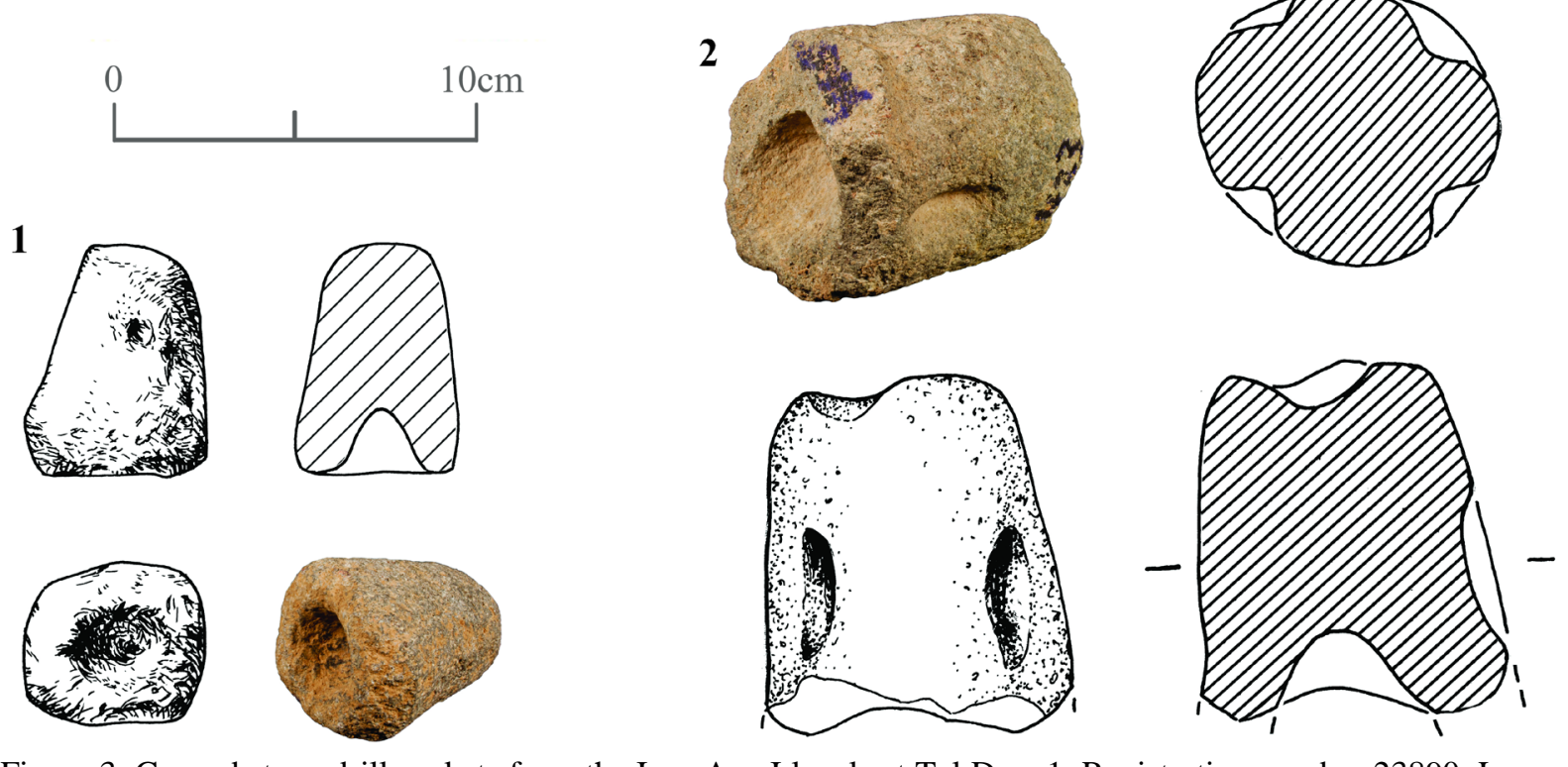

Figure 3. Ground stone drill sockets from the Iron Age I levels at Tel Dan. 1. Registration number 23890, Locus 7151, Serial number 257, upper diameter $34 \mathrm{~mm}$, lower diameter $50 \mathrm{~mm}$, height $65 \mathrm{~mm}$, weight 198 g, complete preservation, Area and phase B9-10, Stratum V. 2. Registration number 23450/10, Locus 7065, Serial number 423, upper diameter 66-80 mm, lower diameter 80-85 mm, height $96 \mathrm{~mm}$, weight $970 \mathrm{~g}$, broken preservation, Area and phase B9-10, Stratum V.

The basalt drill sockets in Figure 3 are from the Iron Age I (ca. 1200-950 BCE) levels at Tel Dan, in northern Israel. Item 1 is the smaller, simpler item with the shape of a rounded cone. Item 2 is broken. It has a roughly cylindrical transverse section and two axial depressions. Four longitudinal grooves of similar size were made equidistant around the circumference at the midsection, perhaps to improve the grip. Lubrication (oil) may have been applied at the contact between the butt of the spindle and the socket interior.

Drill sockets have been identified by Wright et al. (2008: 146, fig. 14a) in a bead-making workshop at the Pre-Pottery Neolithic C site of Jilat 25 in Jordan. A basalt example from a Late Bronze Age I context has been identified by Sass \& Cinamon at Megiddo (2006: 395, 2.19, No. 652) and an Iron Age II example was noted by Sass at Lachish (2004b: fig. 
28.13:10). In the Bronze Age report for Lachish (Sass 2004a), no drill sockets were identified. This is probably a case of serendipity. P.G. Dorrell may have identified one (called a "handrest”) in the Early Bronze Age levels at Jericho (Dorrell 1983: fig. 231:4).

Aside from these, I have not encountered the identification of drill sockets in site reports. Possible unrecognized drill sockets abound; here are some examples (only some), by period:

Some of the "bowlets" of the Sha'ar Hagolan Pottery Neolithic levels are probably drill sockets (Rosenberg \& Garfinkel 2014: figs. 3.68, 3.76, and especially 3.85); Chalcolithic ground stone assemblages at Gilat (Rowan et al. 2006: Fig. 12.18:3, 7), and Horbat 'Illit B (Milevski et al. 2013: fig. 14:1, 4); Small “mortars” from Early Bronze Age Jericho (Dorrell 1983: fig. 231:11,13); Early and Middle Bronze Age artefacts termed "unfinished mace heads” (e.g., Holland 1983: fig. 365: 12-13); Items identified as weights may be drill sockets, such as a Middle Bronze Age item from the City of David (Eran 1996: fig. 31:8); Object \#757 at Tel Gezer, Stratum XI (= Iron Age IA), (Gilmour 2014: pl. 28:3); A shallow late Iron Age I "bowl" from Megiddo Stratum K4 appears to have the striations that might identify it as a socket for a large drill shaft that would be held with two hands (Sass \& Cinamon 2006: fig. 18.5:48) and a shallow Iron Age II limestone "bowl" from Tel Batash is similar to the previous example (Mazar \& Panitz-Cohen 2001: fig. 59:19).

\section{The pump drill}

In the Old World the pump drill is first attested to in the Roman period (Mercer 1975: 212). It is not documented in pictorial representations of the ancient Near East. Whether it was utilised in earlier periods must remain an open question. It is known in the ethnography of indigenous peoples of the Americas, in particular with regard to the Iroquois, who were once credited with its invention (Morgan 1851; Parker 1968:60). But it is noted amongst a number of tribal groups in archaeological contexts, perhaps going back to the Archaic period (circa 8000-1000 BCE; e.g., Hranicky 2011: 736). It is also documented as a tool of premodern northeastern Asian cultures (Hough 1912: 195).

\subsection{Pump drill components}

Pump drills (Figure 4) create rotational friction using a motor principle that differs from that of the bow-drill. A pump drill involves a wooden crossbar perforated at its midpoint, where the drill spindle is inserted into the perforation. A single length of cord is attached to the ends of the wooden crossbar, while also being anchored to the spindle by threading the cord through a perforation at the spindle's top, leaving enough slack to allow the cord to become wrapped tightly around the spindle when spun. Thus the crossbar is positioned tautly toward the top of the spindle. Rotational friction is created, alternately clockwise and counterclockwise, by pumping the crossbar down.

The momentum of the spin rewinds the cord and draws the crossbar back to the upper position. But to acquire sufficient momentum for the rewinding and for the required friction at the spindle point, a flywheel is necessary, positioned under the crossbar, closer to the spindle bit. This flywheel can be of wood or bone, but when heavy-duty drilling is the goal a stone flywheel is used. Like the bow-drill, the point will be either that of the wooden spindle (for making an ember) or a drill bit (of stone or metal), for drilling holes in hard materials.

\subsection{Ground stone features and typological identification}

A stone flywheel will usually be disc-shaped (this is not essential, but will ensure an even momentum). The centre of the wheel is perforated. The diameter of the perforation is a function of the size and weight of the flywheel and the diameter of the spindle (Figure 5). 


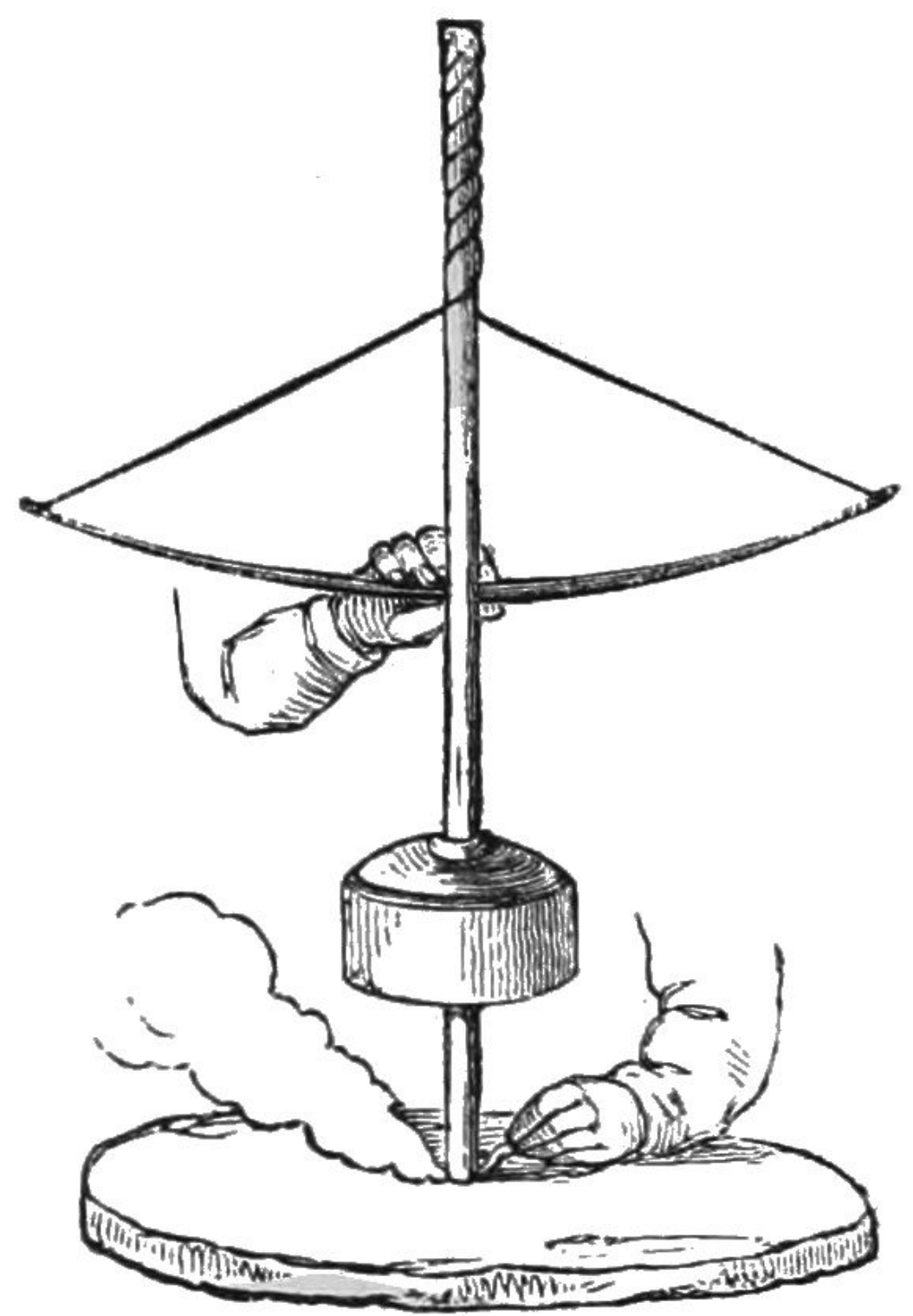

Figure 4. Pump drill components (after Joly 1877: fig.7).

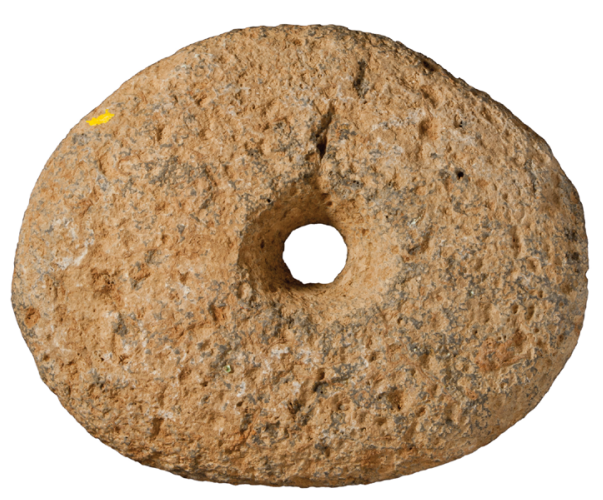

0
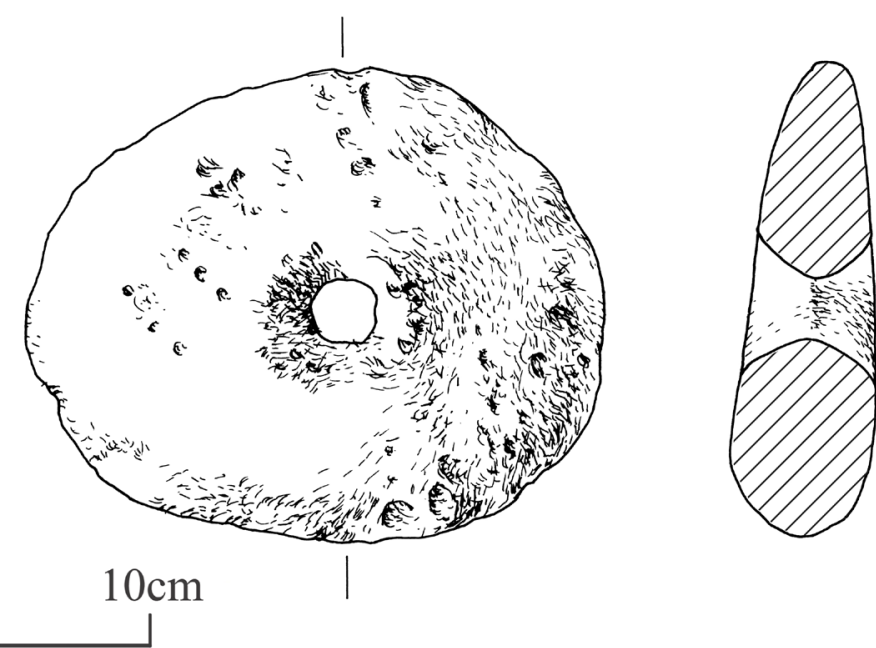

Figure 5. A ground stone perforated disk which is a possible flywheel for a pump drill or a weight for a crank drill; from Tel Dan, Locus 8189 (Stratum V [Iron Age I], Registration number 20672/1), weight: 1.63 kg. 
In the archaeology of the ancient Near East, perforated ground stone disks are often thought to be whorls used in the spinning of textiles into yarn. The key to this interpretation lies in the size and weight of the disk, the diameter of its aperture, and in the morphology of the perforation. A spindle whorl cannot be too large and the aperture cannot be too wide. It might be proposed, therefore, that large perforated disks with broad-aperture perforations were not intended for textile manufacture; one should look for other interpretations. The flywheel is an alternative identification. I must reiterate that no hard evidence has been found for use of the pump drill in pre-Roman contexts. But perforated disks may also have belonged to crank drills (see below). Very large perforated disks may have been weights with other purposes, such as digging stick weights (compare with Amiran \& Ilan 1992: 74-75), or suspension weights.

As a hypothetical exercise, adopting the above criteria, some examples of perforated ground stone disks which could have served as flywheels are presented below in the section on crank drill weights. Pump drill operation is amply demonstrated on the Internet (see, for example, Winn 2014).

\section{The crank drill or borer}

\subsection{Crank drill or borer components}

The crank drill or borer consisted of a wooden shaft with a fork at the base into which a drill bit is inserted (Figures 6 and 7). The fork can be a separate component lashed to the main shaft. At the top of the shaft was a diagonal hand crank, either an integral part of the shaft or attached by lashing. Weights were attached to the upper part of the shaft, at the join with the crank (Stocks 2003: 137-157).
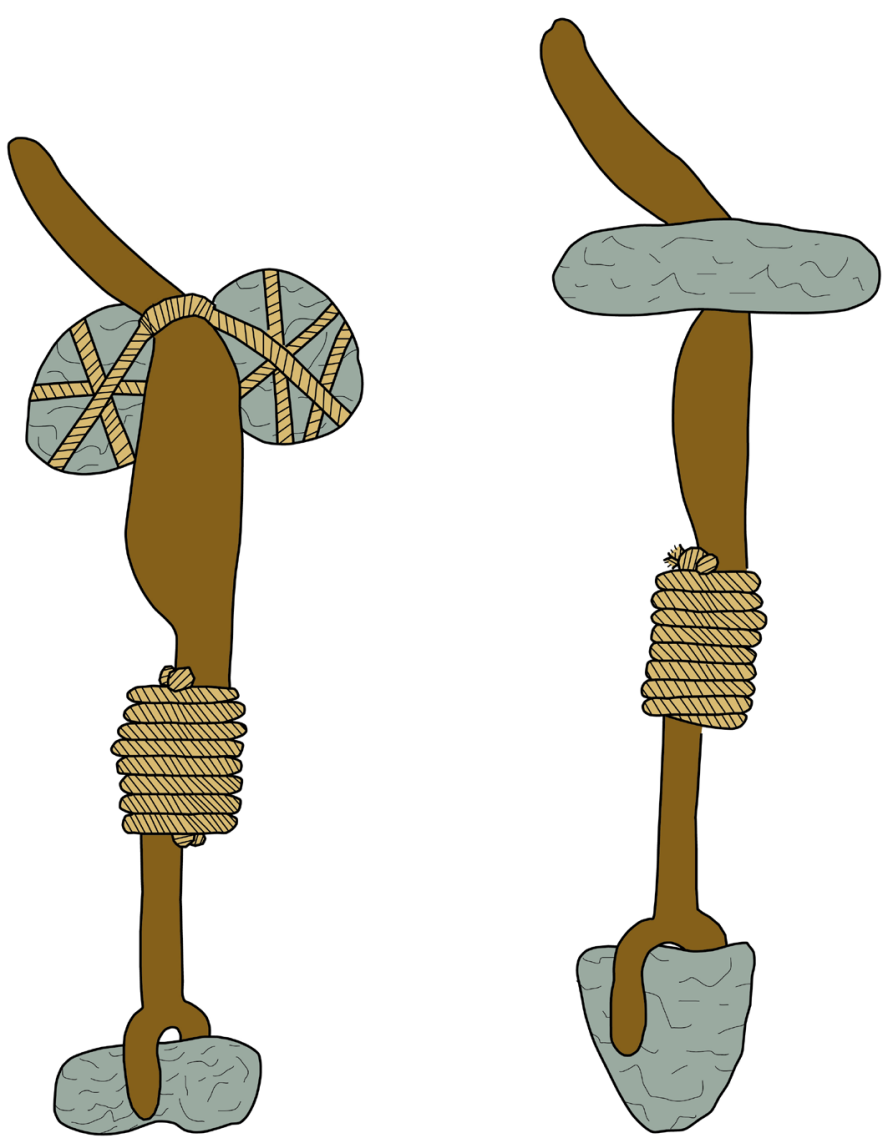

Figure 6. The crank (twist-and-reverse-twist, Stocks 2003: 137) drill and its components. 


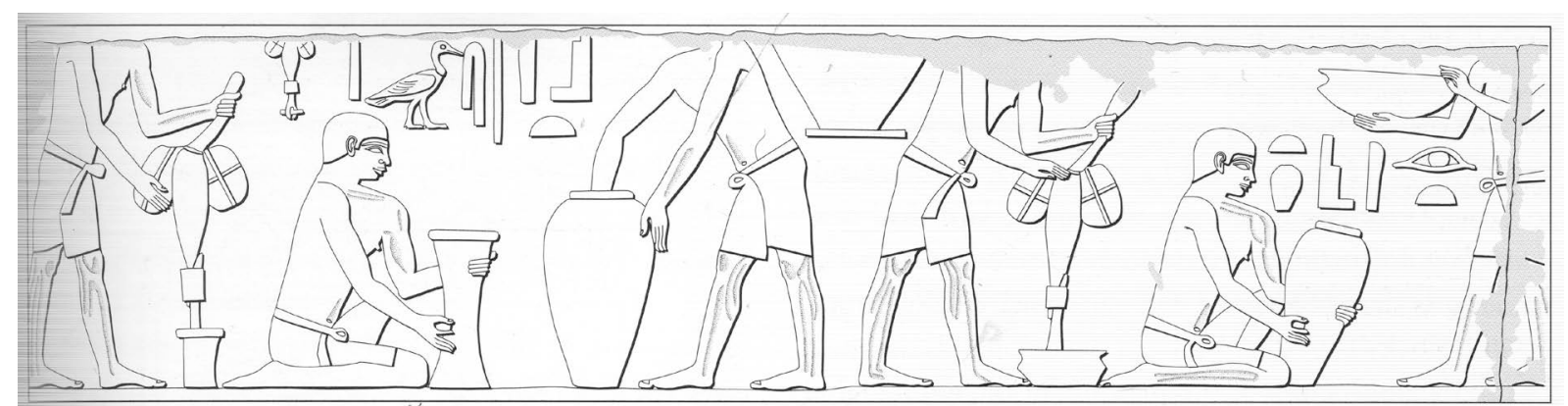

Figure 7. The making of stone vessels as depicted in an Old Kingdom relief from an unknown tomb at Saqqara. Egyptian Museum, Cairo JE 39866. Drawing by P. Der Manuelian after Maspero 1915, pp. 25-27, pl. 22; published in Arnold \& Pischikova 1999: fig. 73; courtesy P. Der Manuelian.

The crank drill or borer was chiefly utilised for stonework, with the help of a sand abrasive. In $4^{\text {th }}$ millennium BCE Egypt the initial rough cavity in stone would have been made by pecking and chiselling and then the crank drill or borer would be put into action. Once copper metallurgy and copper tube corers were introduced in the Naqada II period the twistand-reverse-twist borer with a copper tube bit was employed following the initial shaping (Stocks 2003: 96, 101-105, 133). The resulting cylindrical core was removed with a chisel and the drilling was continued until the desired depth was achieved (Stocks 2003: 122). If a broader cavity was desired, or one that expanded below the tubular neck, a stone bit or borer was then introduced.

In Stocks' (2003: 128-133) experimental study, three different drill bits seem to have been used: (a) a crescent-shaped bit, most often made of flint or chert, (b) a conical or circular bit with hafting grooves at the top (Figure 8), and (c) a "figure-of-eight" or hourglass form that would be grasped at the waist in the wooden fork (Figure 9). The conical type was used for drilling bores that are generally deeper than they are wide and the figure-of-eight type was used to drill wider cavities, expanding and smoothing those begun by other means (Stocks 2003: 131-132). This is particularly germane for the manufacture of closed stone vessels whose openings are narrower than the deeper part of the cavity.

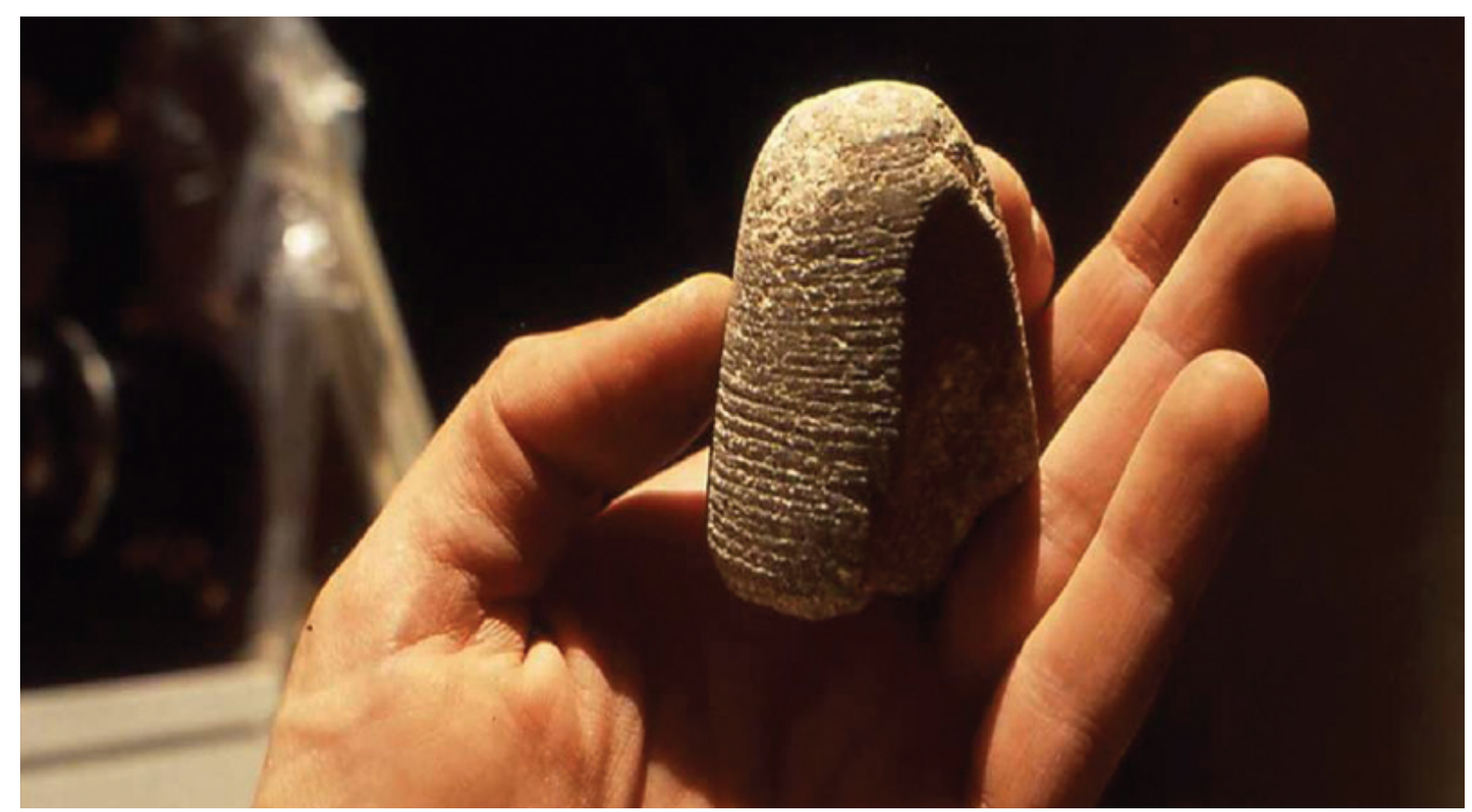

Figure 8. Drill bit of the conical type, from the Lost City of the Pyramids project, Old Kingdom, Giza, Egypt (Tavares 2009:4, courtesy M. Lehner). It is held upside down in the photo. 

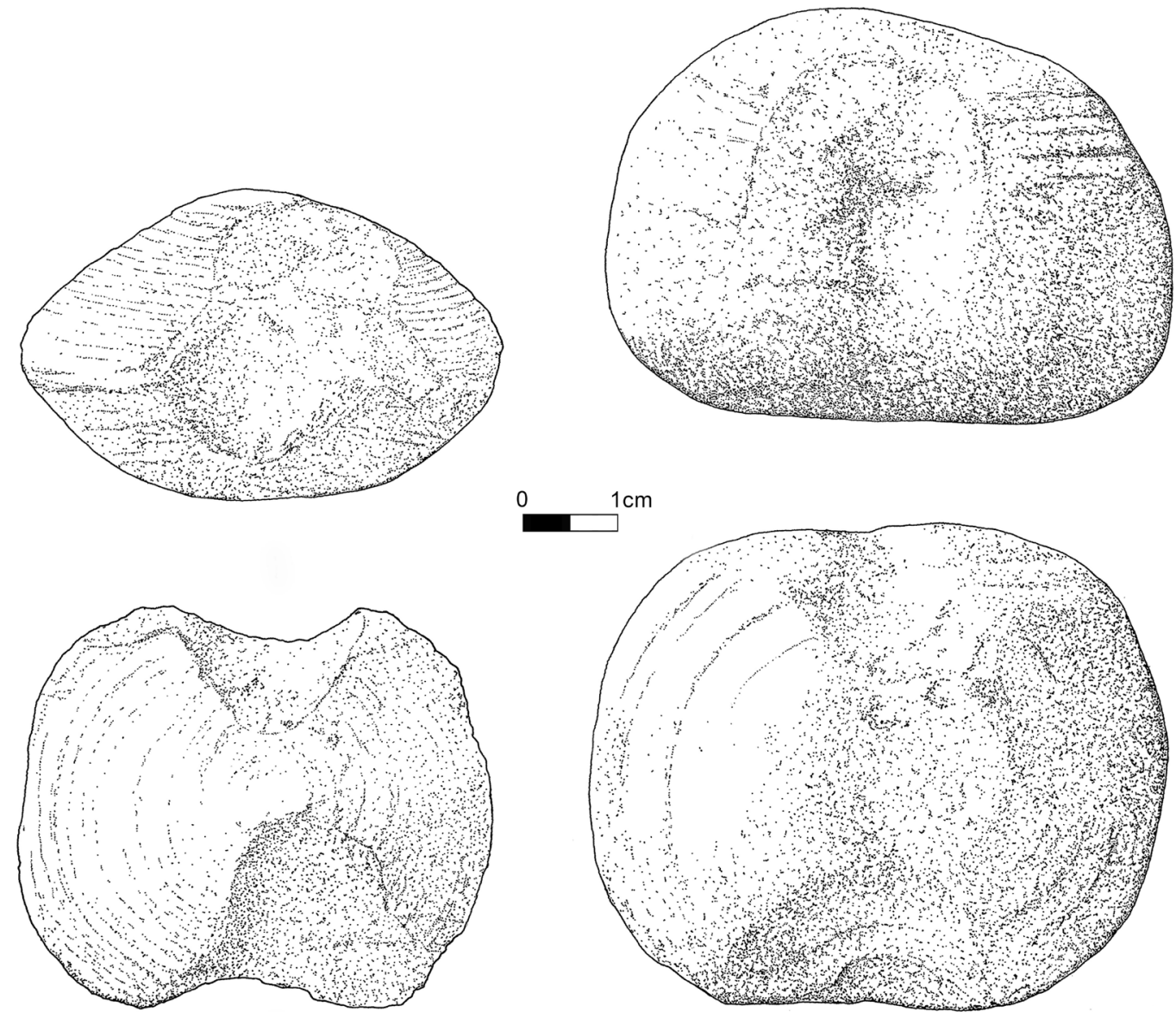

Figure 9. Drill bit of the "figure-of-eight” type, from the Lost City of the Pyramids project, Old Kingdom, Giza, Egypt (Tavares 2009:4, courtesy M. Lehner).

\subsection{Ground stone features and typological identification}

The ground stone components of the crank drill or borer that we are looking for are (a) the stone weights and (b) the drill bits. Weights could take the form of sand-filled bags, which would be irrelevant to our discussion. But they could also, perhaps preferably, take the form of rounded cobbles of uniform weight and shape (Figure 10). Stone weights will be difficult to identify as such if not found in clear association with the other (mostly wooden) components. The cobbles should be smooth so as not to tear the cords that fasten them to the shaft and crank. Their size and weight must conform to the size of the borer apparatus. Smaller drills or borers for the making of stone vessels, for example, would require spheroid or ovoid cobbles with diameters (or length-width measurements) of 10-15 cm and weights in the range of 1-2 kilograms.

The crank was turned clockwise and then counter clockwise, alternately, to ensure both stability and a cantered coring; hence the term "twist-and-reverse-twist drill or borer" (TRTD, Stocks 2003: 136-144).

Denser stones with high specific gravity would be preferred, such as fine-grained basalt, siliceous limestone or flint (at least in the Levantine context). Stone weights for more massive borers could reach 2-3 kilograms (see, for example, Stocks 2003: figs 5.21-5.22). Cobbles of this sort are perhaps best available as naturally ground river cobbles; but if these are not available, quarried stones can be ground to the appropriate shape.

Another form of drill or borer weight came into vogue in Egypt in the Middle Kingdom and remained popular (together with the double-weighted variety) throughout the New Kingdom. This was a stone ring perforated at its centre through which the drill or borer shaft 
was passed (Figure 5; Stocks 2003: 132-133, fig. 5.17). It is essentially a flywheel, but placed higher up, just below the crank. It can be a flat ring or domed (the domed form is Gardiner's (1957) hieroglyphic sign U24, see below Figure 12).

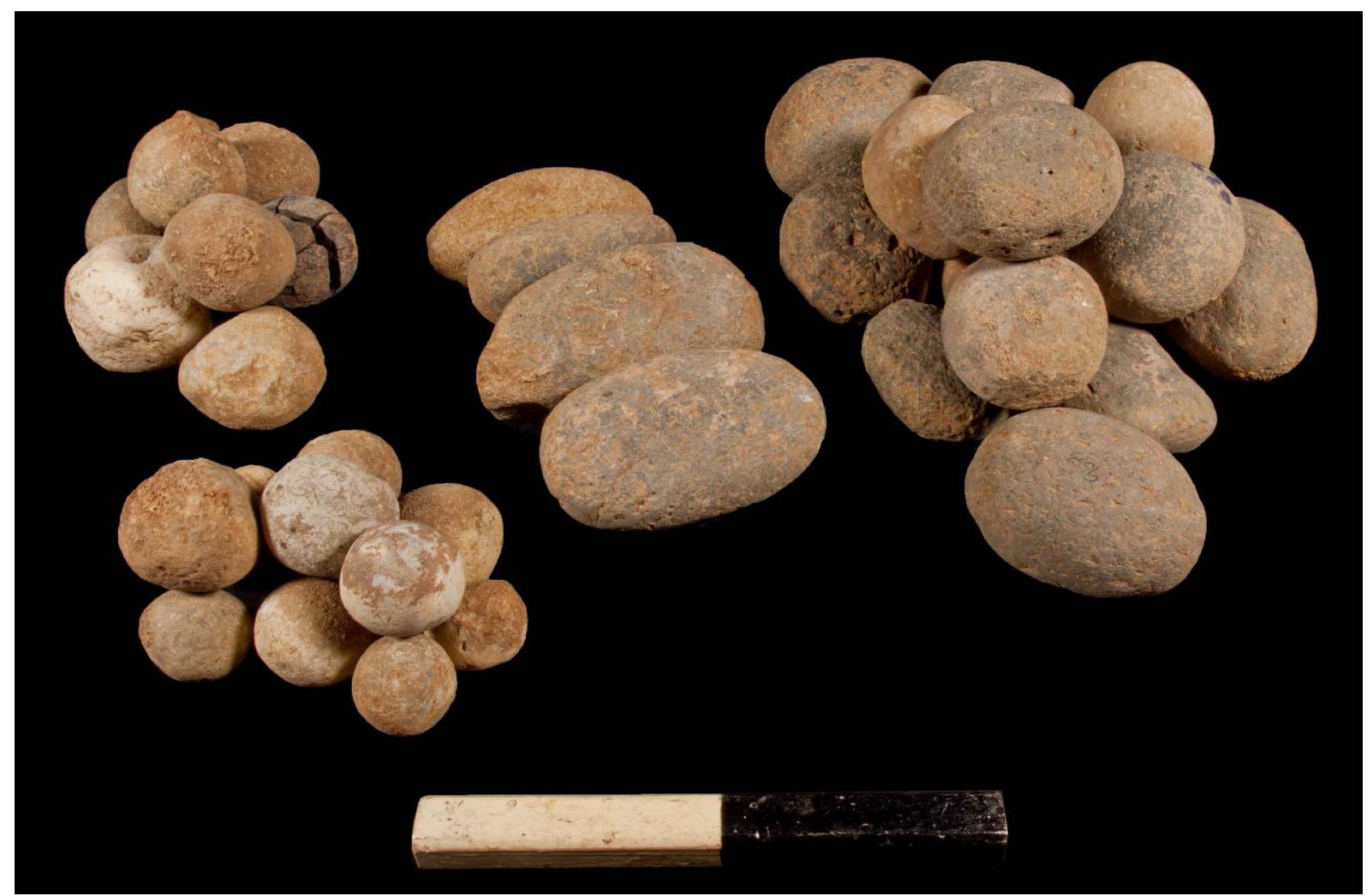

Figure 10. Cobbles from Iron Age I Tel Dan: some of these could have functioned as crank drill or borer weights (the two groupings on the right; the small spherical cobbles on the left are too small).

Almost every Levantine ground stone assemblage contains a few rings of this type. One might identify possible crank drill or borer ring weights in the recent publications of, for example, Beth-Shan (Iron Age I-IIA; Yahalom-Mack \& Panitz-Cohen 2009: fig. 14.6), Yesodot (Middle-Late Bronze Age; Ilan et al. 2012: fig. 6.1.1), Tel Gezer (one from a Macalister excavation backfill and one from a Middle Bronze III-Late Bronze I context: Gilmour 2014: 166, 175, Object nos. 1877, 2177; pls. 20:3; 32:3), and Tel Jemmeh (Middle Bronze Age; Rowan 2014: fig. 23.4.n). As mentioned above, these rings could also be, theoretically, flywheels of pump drills.

Drill bits will be manufactured of minerals with a hardness of more than 7 on the Mohs scale. In a Levantine context, fine-grained basalt, siliceous limestone, quartzite, or flint would be suitable. In neighbouring regions various crystalline igneous minerals, such as granite or diorite, might be used, where available, though siliceous limestone may be the preferred material (see the below discussion of Shaykh Sa ${ }^{\mathrm{i}} \mathrm{id}-$ Wadi Zabayda in Egypt).

The earliest representation of the crank drill or borer appears as a hieroglyph in a $3^{\text {rd }}$ Dynasty tomb at Saqqara (Firth \& Quibell 1935-1936: pl. 93). The earliest naturalistic depictions are found in Egyptian wall reliefs of the $5^{\text {th }}$ dynasty, such as the tomb of Ty (Steindorff 1913: pl. 134) and the $6^{\text {th }}$ dynasty tomb of Mereruka (Duell 1938: Part I, pls. 3031) at Saqqara. It appears thereafter in wall reliefs until the $26^{\text {th }}$ dynasty (Stocks 2003: 132136; Lucas \& Harris 2012: 425). A wooden model dating to the Middle Kingdom was recovered from the north side of the Teti Pyramid complex (No. J. 45319 in Quibell \& Hayter 1927: 40, pl. 24). 
Stone weights of crank drills or borers were identified by Rowe (1931: 41, pl. 15) at Meydum, and both weights and bits were documented at number of other locations: Saqqara (Lauer 1936: vol. I: 234-235, vol. II, pl. 96, vol. III: 74-75, pl. 19), Hierakonpolis (Quibell \& Green 1900: vol. II: 17, 49, pls. 32:3, 62, 68), Abydos (Petrie 1902: 25-26, pl. 53), Meydum and Memphis (Petrie et al. 1910: 44, pl. 39:2), and Naqada and Ballas (Quibell \& Petrie 1895: pl. 75).

More recently, a group of drill bits was reported from the "Lost City of the Pyramids" project (Old Kingdom) at Giza (Tavares 2009). And a 1000+ assemblage of drill bits of five different types was reported at Al-Shaykh $\mathrm{Sa}^{\mathrm{c}} \mathrm{id}$-Wadi Zabayda near Hermopolis in Middle Egypt (Figure 11; Willems et al. 2009). This site has been identified as a calcite alabaster vessel manufacturing workshop, probably dating to the New Kingdom and the Third Intermediate Period, though it is possible that some of the stone bits date to the Old Kingdom. The large majority of the bits are of silicified limestone. The pattern of wear striations was a key factor in their identification as drill-bits. The five types were determined as follows (and see Willems et al. 2009 for detailed descriptions):

1. Figure-of-eight (Petrie’s (1917) “hour-glass borer”) type; $N$ = approximately 20; here Figure 11A.

2. Boat-shaped; $N=65$; here Figure 11B. This is a newly identified form.

3. Vertically oblong; $\mathrm{N}=$ approximately 170 ; here Figure 11C-D. This type shows a wide variety of forms ranging from long and thin (Figure 11C) to long and broad (Figure 11D).

4. Discoidal with flat undersides; $N=$ approximately 10; here Figure 11E. These often seem to be "remodelled" old tools. They are also a newly identified drill-bit form.

5. Bits with shallow hollows; $\mathrm{N}=$ approximately 45; here Figure 11F.

An additional circa 200 crescent-shaped drill bits of flint were recovered, but these are not within the purview of this article.

As noted above, the crank drill or borer appears to be the origin of the hieroglyphs U24 (Old Kingdom) and U25 (New Kingdom) in Gardiner's (1957) list (Figure 12). They are determinatives for crafts.

For Mesopotamia, Moorey (1994: 56-58) has provided the best summary of the few finds related to the crank drill or borer. He notes the "figure-of-eight" stone drill bits found at Neolithic Jarmo (Moholy-Nagy 1983: 294, figs. 132:7, 140:8), protohistoric Ur (drill sockets too: Woolley 1956: pls. 13:U.1640, 15:U.14925), though Woolley believed such bits to be associated with the bow drill), and Uruk (Eichmann 1987:110). Woolley identified “...stone borers for hollowing stone vases...common in the Uruk and Jamdat Nasr periods; the drillpoint is a circular stone, flat on the top and curved underneath, and from each side a piece is cut out for attachment; the shaft of the drill would be made of two pieces of wood laid together (or one piece forked at one end ...[which] gripped the stone drill head" (Woolley 1956: 14, fig. 5).

More recent analyses of masonry involving stone drill bits - stone bowl making in this case - have been presented by Ciarla \& Bökönyi (1985) and Bocutti et al. (2015) for the Early Bronze Age levels at the site of Shahr-i Sokhta in eastern Iran, where stone drill bits were identified tentatively (Ciarla \& Bökönyi 1985: fig. 8a: 4c). In the Levant, at least one study of Neolithic "cupmarks" - suggests a very early use of the crank drill or borer (Grossman \& Goren-Inbar 2007). 


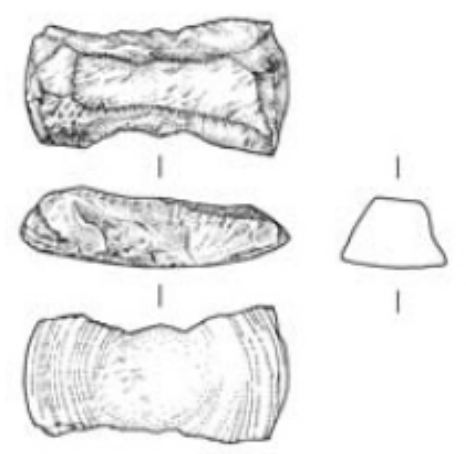

A)
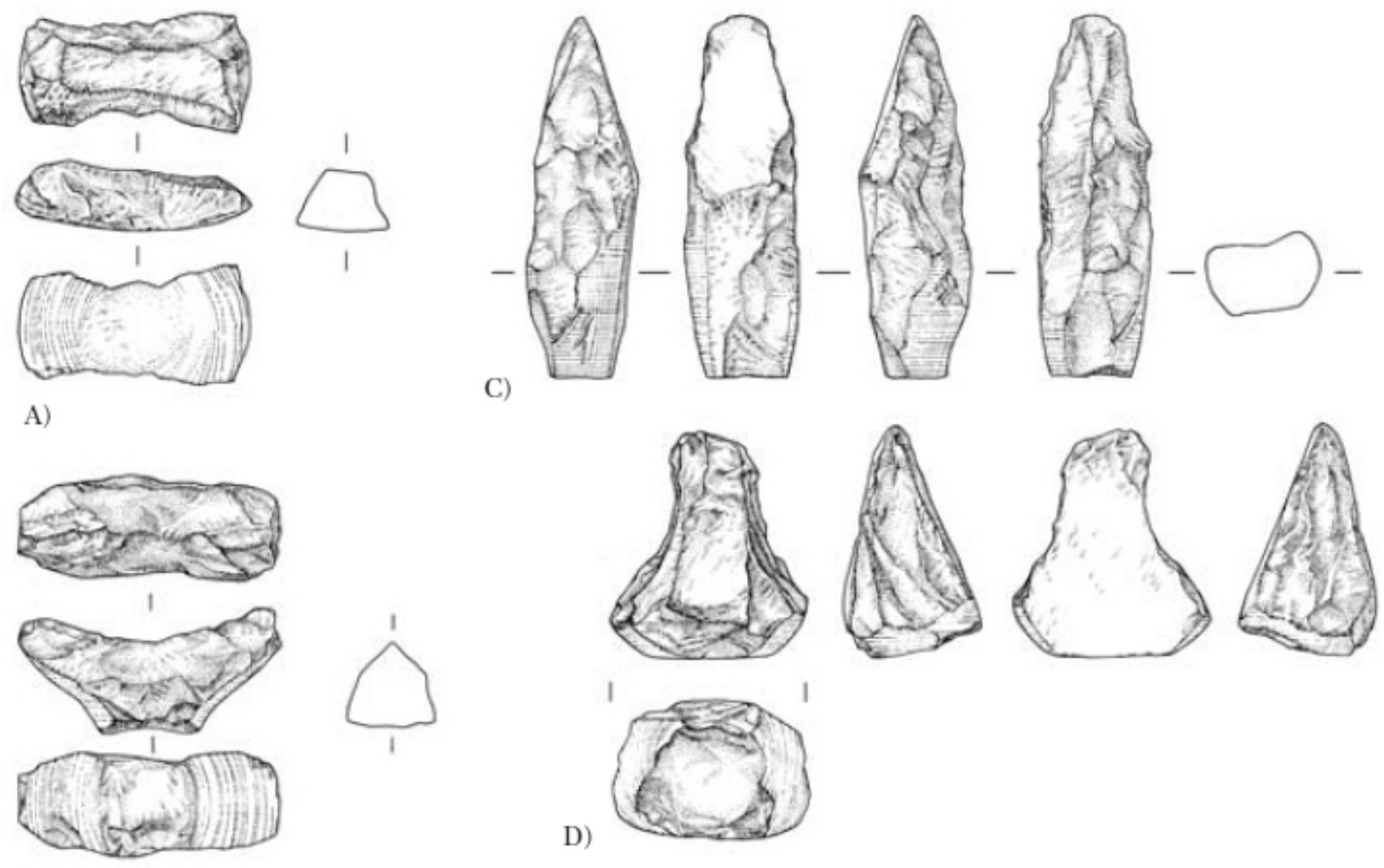

B)

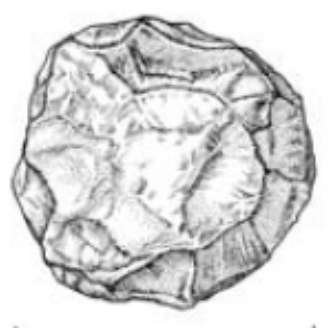

I

1

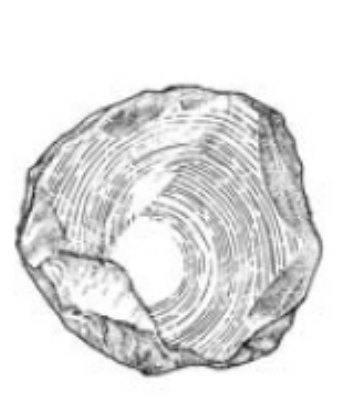

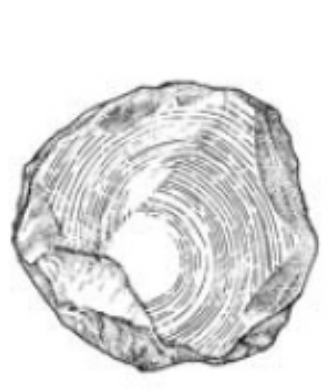

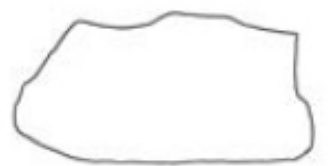

E)
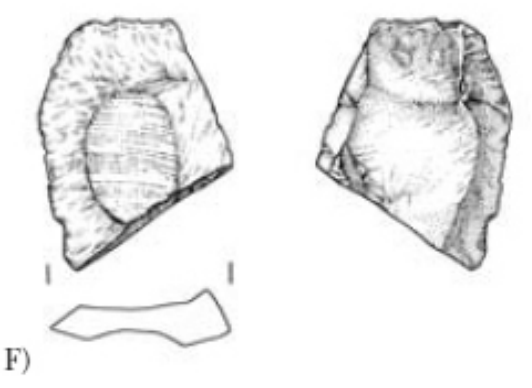

F)

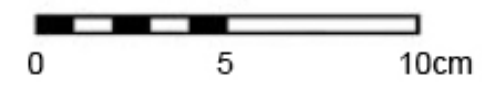

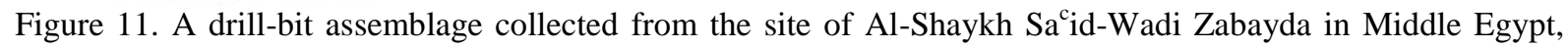
dating to the New Kingdom (1550-1069 BCE) and Third Intermediate Period (1069-653 BCE), (source: Willems et al. 2009: fig. 3; drawings by A. van den Broeck).
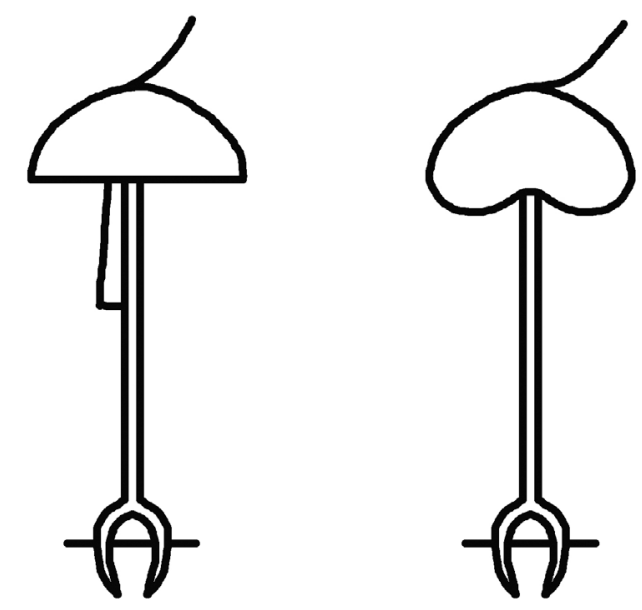

Figure 12. Hieroglyphs derived from the crank drill or borer, Gardiner's (1957) signs U24 and U25. 


\section{Concluding Remarks}

This paper has described the components and utilization of three different types of drill: the bow drill, the pump drill and the crank drill. This is essentially a summary of previous research, without any intention of complete coverage. More specifically, I have emphasised the ground stone components of each of these drill types. A survey of the literature shows that these somewhat unbecoming stone artefacts are most often either ignored or misinterpreted as either other artefact types or, in the case of cobbles, not considered artefacts at all. Since other drill components are organic and therefore only rarely preserved in archaeological contexts, the misidentification of stone drill parts means that drills are largely missing from spatialfunctional site interpretations. If the interpretations presented here are correct, drills of different kinds were commonplace at almost every site. The author hopes that this contribution will encourage the identification of drills in future field work and that drills will be given their rightful place in material culture analysis. Certainly, a more comprehensive study should be carried out, including experimental work with the aim of defining the specific qualities and metrics of drill components made of ground stone, and a more complete, contextualized cataloguing of such items from archaeological contexts.

\section{Acknowledgements}

I would like to thank D. Rosenberg for pointing out the work of K. Wright at Jilat, Y. Rowan for his insights concerning the Gilat assemblage, and A. Squiteri for informing me of his and his colleagues work at Shahr-I Sokhta. I was also glad to integrate the comments of two anonymous reviewers.

\section{References}

Amiran, R., \& Ilan, O. 1992, Arad, eine 5000 Jahre Stadt in der Wüste Negev, Israel. Veroffentlichungen des Hamburger Museums fur Archaologie und die Geschichte Harburgs-Helms-Museum, Karl Wachholtz Verlag, Hamburg, 115 p. (in German) (Arad, a 5000 year city in the Negev desert, Israel)

Arnold, D., \& Pischikova, E. 1999, Stone vessels: luxury items with manifold implications. In: Egyptian Art in the Age of the Pyramids (O’NeilL, J.P., Fuerstein, C., Childs Allison, E., Donovan, M. \& Howard, K., Eds.), The Metropolitan Museum of Art, New York: p. 121-131.

Boccuti, S., Squitieri, A., Angelini, G., Lazzari, A., Di Luzio, E., \& Albano, M. 2015, Preliminary surface analyses by ESEM-EDS of calcite bowls from Shahr-i Sokhta (Sistan, Iran, ca. 3200-1800 BCE): Results and possible interpretations. Journal of Archaeological Science, 61: 244-259. doi:10.1016/j.jas.2015.06.005

Ciarla, R., \& Bökönyi, S. 1985, Elaboration of data from Shahr-i Sokhta Excavations. East and West, 35(4): 418-429. URL: http://www.jstor.org/stable/29756748

Davies, N. de G. 1935, Paintings from the Tomb of Rekh-mi-Re at Thebes, Publications of the Metropolitan Museum of Art Egyptian Expedition, New York, 9 p.

Dorrell, P.G. 1983, Appendix A - stone vessels, tools, and objects. In: Excavations at Jericho, Volume Five, The Pottery Phases of the Tell and Other Finds, (Kenyon, K.M. \& Holland, T.A., Eds.), Council for British Research in the Levant, London: p. 485-575.

Duell, P. 1938, The Mastaba of Mereruka. Part I. University of Chicago Press, Chicago, $\mathrm{xxv}+18 \mathrm{p}$. 
Eichmann, R. 1987, Uruk-Warka XXXVIII. Oberflächenfunde III: Steingefässbohrer. Baghdader Mitteilungen, 18: 107-115. (in German) (Uruk-Warka XXXVIII. Surface finds III: Stone vessel drills)

Endo, H., Takamiya, I., \& Friedman, R. 2009, 2009 Field Note 3 - Beads and Bead Making at Hierakonpolis. Archaeology's Interactive Dig; Digging Hierankopolis, Accessed: 20 September 2015. URL: http://interactive.archaeology.org/hierakonpolis/field09/3.html

Eran, A. 1996, Weights and weighing in the City of David: the early weights from the Bronze Age to the Persian Period. In: Excavations at the City of David 1978-1985, Directed by Yigal Shiloh. Vol. 4 (Ariel, D.T. \& de Groot, A., Eds.), Qedem Vol. 35, Hebrew University of Jerusalem - Institute of Archaeology, Jerusalem: p. 204-256.

Firth, C.M. \& Quibell, J.E. 1935-1936, Excavations at Saqqara: the Step Pyramid. Vol. 1 \& 2. Imprimerie de L'Institut Française d'Archéologie Orientale, Cairo, 144 p.

Gardiner, A. 1957, Egyptian Grammar: Being an Introduction to the Study of Hieroglyphs, 3rd edition, Griffith Institute, Oxford, 646 p.

Gilmour, G. 2014, Gezer VI, The Objects from Phases I and II 1964-1974. Annual of the Nelson Glueck School of Biblical Archaeology Vol. 10, Eisenbrauns, Winona Lake, $400 \mathrm{p}$.

Goren-Inbar, N., Friekman, M., Garfinkel, Y., Goring-Morris, N.A., \& Grosman, L. 2012, The earliest matches. PLOS ONE, 7(8) e42213. doi:10.1371/journal.pone.0042213

Gorelick, L., \& Gwinnett, A.J. 1987, A history of drills and drilling. New York State Dental Journal, 53: 35-39.

Grossman, L., \& Goren-Inbar, N. 2007, “Taming” rocks and changing landscapes: a new interpretation of Neolithic cupmarks. Current Anthropology, 48(5): 732-740. doi:10.1086/520966

Gwinnett, A.J., \& Gorelick, L. 1987, The change from stone drills to copper drills in Mesopotamia, an experimental perspective. Expedition, 29(3): 15-24.

URL: http://www.penn.museum/documents/publications/expedition/pdfs/293/gwinnett.pdf

Gwinnett, A.J. \& Gorelick, L. 1993, Beads, scarabs, and amulets: methods of manufacture in Ancient Egypt. Journal of the American Research Center in Egypt, 30: 125-132. doi:10.2307/40000232

Hartenberg, R.S., \& Schmidt, J.Jr. 1969, The Egyptian drill and the origin of the crank. Technology and Culture, 10: 155-165. URL: http://www.jstor.org/stable/3101475

Holland, T.A. 1983, Appendix M. Stone mace-heads. In: Excavations at Jericho, Volume Five, The Pottery Phases of the Tell and Other Finds, (Kenyon, K.M. \& Holland, T.A., Eds.), Council for British Research in the Levant, London: p. 485-575.

Hough, W. 1976 [1912], Some ethnological aspects of the problem. American Anthropologist. New Series, 14(1): The Problems of the Unity of Plurality and the Probable Place of Origin of the American Aborigines: A Symposium (republished as American Anthropology 1888-1920, de Laguna, F., Ed.), Lincoln, Nebraska and London: p. 194197.

Hranicky, W.J. 2011, Material Culture from Prehistoric Virginia, Vol. 2, AuthorHouse, Bloomington, $548 \mathrm{p}$. 
Ilan, D., Ben-Ari, N., \& Levitte, D. 2012, Chapter 6 - The ground stone objects. NGSBA Archaeology, Vol. 1 (Salvage Excavations at Yesodot (Khirbet Umm el-Kalkha), the Middle and Late Bronze Age Settlement (Govrin, Y., Ben-Ari, N., \& Ilan, D., Eds.): 6368.

Joly, N. 1877, The early history of fire. Popular Science Monthly, 10: 17-23.

URL: https://archive.org/details/popularsciencemo10newy

Lauer, J.P. 1936, La Pyramide à Degrés: l'Architecture, Vol. 1. Institut Francais d'Archéologie Orientale, Cairo, 254 p.

Lucas, A., \& Harris, J. 2012, Ancient Egyptian Materials and Industries. Dover Publications, New York, 554 p.

Maspero, G. 1915, Le Musée Egyptien: Recueil de Monuments et de Notices sur les Fouilles d'Egypte. Vol. 3. Institut Français d'Archéologie Orientale, le Caire, 97 p.

Mazar, A., \& Panitz-Cohen, N. 2001, Timnah (Tel Batash) II, the Finds from the First Millennium BCE, Qedem Vol. 42. Institute of Archaeology, Hebrew University of Jerusalem, Jerusalem, 355 p.

Mercer, H.C. 1975, Ancient Carpenters' Tools: Illustrated and Explained, Together with the Implements of the Lumberman, Joiner and Cabinet-Maker in Use in the Eighteenth Century, Dover Publications, Doylestown, 339 p.

Milevski, I., Vardi, J., Gilead, I., Eirikh-Rose, A., Birkenfeld, M., Mienis, H.K., \& Kolska Horwitz, L. 2013, Excavations at Horbat 'Illit B: a Chalcolithic (Ghassulian) site in the Haelah Valley. Journal of the Israel Prehistoric Society, 43: 73-147.

Moholy-Nagy, H. 1983, Jarmo artifacts of pecked and ground stone and of shell. In: Prehistoric Archaeology along the Zagros Flanks (Braidwood, L.S., Braidwood, R.J., Howe, B., Reed, C.A., \& Watson, P.J., Eds.), Oriental Institute Publications Vol. 105, Chicago: p. 289-346.

Moorey, P.R.S. 1994, Ancient Mesopotamian Materials and Industries: The Archaeological Evidence, Clarendon Press, Oxford, 436 p.

Morero, E. 2011, Transferts techniques en Méditerranée orientale. L’exemple de la fabrication des vases de pierre à l'âge du bronze. Syria, 88: 207-224. (in French) (Technical transfers in the Eastern Mediterranean. The example of making stone pots in the Bronze Age).

Morgan, L.H. 1851, Report on the fabrics, inventions, implements, and utensils of the Iroquois, made to the regents of the university, Jan. 22, 1851, by Lewis H. Morgan, illustrative of the collection annexed to the State Cabinet of Natural History. Fifth Annual Report of the Regents of the University on the Condition of the State Cabinet of Natural History, and the Historical and Antiquarian Collection Annexed Thereto, Charles van Benthuysen, Albany, New York: 67-117.

National Geographic Channel. 2014, How to build a bow-drill fire. Live Free or Die. URL: http://channel.nationalgeographic.com/live-free-or-die/videos/live-free-or-diediy-how-to-build-a-bow-drill-fire/ Accessed April 3, 2016.

Parker, A.C. 1968, Parker on the Iroquois, Syracuse University Press, New York, 472 p.

Petrie, W.M.F. 1884, On the mechanical methods of the ancient Egyptians. Journal of Anthropological Institute, 13: 88-109. 
Petrie, W.M.F. 1902, Abydos, Vol. 1, London, Offices of the Egypt Exploration Fund, London, 259 p.

Petrie, W.M.F. 1917, Tools and Weapons. British School of Archaeology in Egypt, Constable \& Co Ltd., London, $71 \mathrm{p}$.

Petrie, W.M.F., Mackay, E., \& Wainwright. G. 1910, Meydum and Memphis, Vol 3. British School of Archaeology in Egypt and Egyptian Research Account, London, 162 p.

Quibell, J.E. \& Green, F.W. 1900 (reprinted 2009), Hierakonpolis, B. Quaritch, London, $108 \mathrm{p}$.

Quibell, J.E. \& Hayter, A.G.K. 1927, Excavations at Saqqara: Teti Pyramid, North Side, Institut Francais d'Archeologie Orientale, Cairo, London, 44 p.

Quibell, J.E., \& Petrie, W.M.F. 1895, Naqada and Ballas, British School of Archaeology in Egypt, London, $272 \mathrm{p}$.

Rosen, S.A. 1997, Lithics After the Stone Age - A Handbook of Stone Tools from the Levant, Altamira Press, Walnut Creek, 184 p.

Rosenberg, D., \& Garfinkel, Y. 2014, Sha'ar Hagolan 4: The Ground stone Industry: Stone Working at the Dawn of Pottery Production in the Southern Levant. Institute of Archaeology, The Hebrew University of Jerusalem, Jerusalem, 336 p.

Rowan, Y.M, Levy, T.E., Alon, D., \& Kansa, E. 2006. Gilat’s ground stone assemblage: stone fenestrated stands, bowls, palettes and related artifacts. In: Archaeology, Anthropology and Cult - the Sanctuary at Gilat, Israel (Levy, T.E., Ed.), Routledge, London: p. 575684.

Rowan, Y. 2014, Chapter 23, Stone artifact assemblage from Tell Jemmeh. In: The Smithsonian Institution Excavation at Tell Jemmeh, Israel, 1970-1990 (Ben-Shlomo, D., \& Van Beek, G.W., Eds.), Smithsonian Contributions to Anthropology Vol. 50, Washington D.C.: p. 917-969.

Rowe, A. 1931, Excavations at Medum. The Museum Journal, 22: 3-84.

Saraydar, S.C. 2012, The Egyptian drill: a unique dual-mode device. Ethnoarchaeology, 4(1): 37-52.

Sass, B. 2004a, Pre-Bronze Age and Bronze Age artefacts. In: The Renewed Archaeological Excavations at Lachish (1973-1994), Vol. 4, (Ussishkin, D., Ed.), Sonia and Marco Nadler Institute of Archaeology Monograph Series Vol. 22, Tel Aviv: p. 1450-1524.

Sass, B. 2004b, Iron Age and Post-Iron Age artefacts. In: The Renewed Archaeological Excavations at Lachish (1973-1994), Vol. 4, (Ussishkin, D., Ed.), Sonia and Marco Nadler Institute of Archaeology Monograph Series Vol. 22, Tel Aviv: p. 1983-2057.

Sass, B. \& Cinamon, G. 2006, The small finds. In: Megiddo IV: The 1998-2002 Seasons, Vol. 1, (Finkelstein, I., Ussishkin, D., \& Halpern, B., Eds.), Sonia and Marco Nadler Institute of Archaeology Monograph Series Vol. 24, Tel Aviv: p. 353-425.

Science Channel. 2009, Egyptian Drill. What the Ancients Knew.

URL: http://www.sciencechannel.com/tv-shows/what-the-ancients-knew/videos/whatthe-ancients-knew-i-shorts-egyptian-drill/ Accessed April 3, 2016.

Steindorff, G. 1913, Das Grab de Ti. Hinrichs, Leipzig, 12 p. (in German) (“The tomb of Ti”) 
Stocks, D. 2003, Experiments in Egyptian Archaeology: Stoneworking technology in Ancient Egypt. Routledge, London, 296 p.

Tavares, S. 2009, Small finds, big results: inconspicuous stones a key to an ancient industry. Aeragram, 9(2): 4-5. URL: http://www.aeraweb.org/wpcontent/uploads/2009/09/Aeragram-9-2.pdf

Wilkinson, J.G. 1878, The Manners and Customs of the Ancient Egyptians. Vol. 1, John Murray, London, p. 464. URL: https://archive.org/details/mannerscustomsof01wilk_1

Willems, H., Vereecken, S., Kuijper, L., Vanthuyne, B., Marinova, E., Linseele, V., Verstraeten, G., Hendrickx, S., Eyckerman, M., Van den Broeck, A., Van Neer, W., Bourriau, J., French, P., Peeters, C., De Laet, V., Mortier, S., \& De Kooning, Z. 2009, An industrial site at Al-Shaykh Sacid/Wadi Zabayda. Ägypten und Levante, 19: 293331. URL: http://www.jstor.org/stable/23788595

Winn, J., (director), 2014, How to Make a Pump Drill. YouTube. Running time: 8m, 23s. URL: https://youtu.be/c6wRLJWfjFw

Woolley, C.L. 1956, Ur Excavations IV: The Early Periods, The British Museum Press, London and Philadelphia, 225 p.

URL: http://www.etana.org/sites/default/files/coretexts/20262.pdf

Wright, K. 1992, Classification system for ground stone tools from the prehistoric Levant. Paléorient, 18(2): 53-80. doi:10.3406/paleo.1992.4573

Wright, K.I, Critchley, P., \& Garrard, A., Baird D., Bains, R., Groom, S. 2008, Stone bead technologies and early craft specialization: insights from two Neolithic sites in Eastern Jordan. Levant, 40: 131-165. doi:10.1179/175638008X348016

Yahalom-Mack, N. 2009, Bronze in the Beginning of the Iron Age in the Land of Israel: Production and Utilization in a Diverse Ethno-Political Setting. Ph.D dissertation. Hebrew University of Jerusalem, Jerusalem, 298 p.

Yahalom-Mack, N. \& Panitz-Cohen, N. 2009, Groundstone implements. In: Excavations at Tel Beth-Shean 1989-1996 Volume III: The 13th-11th Century BCE Strata in Areas N and $S$ (Panitz-Cohen, N. and Mazar, A., Eds.). The Institute of Archaeology, The Hebrew University of Jerusalem, Jerusalem: p. 719-736. 